\title{
Development of Mobile Learning integrated with Learning Management System (LMS) on Buffer Solutions Topic
}

\author{
Ucu Cahyana ${ }^{*}$, Farihatul Janah ${ }^{1}$ and Setia Budi ${ }^{1}$ \\ ${ }^{1}$ Department of Chemistry Education, Universitas Negeri Jakarta, Jl. Rawamangun Muka, \\ Jakarta 13220, Indonesia \\ *Email: ucahyana@unj.ac.id
}

Received: 21 September 2021; Accepted: 26 December 2021; Published: 31 December 2021

\begin{abstract}
This research aims to develop mobile learning integrated with LMS and test its effectiveness motivation learning on the topic of buffer solutions. The research was conducted at SMA AL-HASRA from November 2020 to June 2021. The research and development method by Borg and Gall was used by modifying five stages, needs analysis; product development; validation; product testing; and implementation. Testing used quantitative method with post-test only control group design and analysis using independent sample t-test. The resulting mobile learning medium is called "LarutanPenyangga.apk" which is compatible with Android devices which provides summaries, video animations, kimi, quiz, and application buffer solutions in daily life. The feasibility test for topic and language resulted $82.25 \%$ with a reliability 0.975 . The feasibility test for media $75.05 \%$ with a reliability 0.960 . Trial test have very good criteria. The effectiveness test of motivation learning percentage is $68,4 \%$ and has a good category. Based on the $t$-test, obtained $t_{\text {table }}<t_{\text {count. }}$. It can be concluded that $\mathrm{H}_{0}$ is rejected and $\mathrm{H}_{1}$ is accepted, which means that there is a significant positive effect from the use of integrated mobile learning with LMS to increase students' learning motivation on buffer solutions topic.
\end{abstract}

Keywords: LMS, mobile learning, motivation learning

DOI: http://dx.doi.org/10.15575/jtk.v6i2.13936

\section{Introduction}

The development of the $21^{\text {st }}$-century is marked by the increasing importance of information and communication technology in many aspects of human life. Information and communication technology have become a tool used in developing a more dynamic and quality learning process in education. With the information and communication technology (ICT) integrated with education, it is possible to exchange and distribute information to others, so that learning can be done anytime and anywhere (Silin \& Kwok, 2017). Almost all information in all fields can be changed and displayed in digital form, including learning materials so that students can do independent learning with their ICT tools without the limitations of space and time (Asmara, 2015; Silin \& Kwok, 2017).
In November 2019, a new virus was discovered, named Covid-19. Starting from Wuhan, then spread throughout the world, including Indonesia. Positive cases of Covid19 in Indonesia were first detected in March 2020. The spread of Covid-19 had a massive impact on the world economy, but now the impact is starting to be felt by the world of education (Abidah et al., 2020). Therefore, the ministry of education and culture decided to implement distance learning. Reporting from the Ministry of Education and Culture (Kemendikbud) issued Circular Letter Number 15 of 2020 concerning Guidelines for the Implementation of Learning from Home in an Emergency Period for the Spread of Covid-19. This circular letter reinforces the contents of the Circular Letter of the Minister of Education and Culture Number 4 of 2020 concerning the Implementation of Education in the Corona 
Covid-19 Emergency Period (Kemendikbud, 2020). The online learning system (in the network) is a learning system without face-toface directly between teachers and students but is carried out online using the internet network. Teachers must ensure that teaching and learning activities continue, even though students are home. The solution is that teachers must design learning media as innovations by utilizing online media.

The use of mobile phones has increased during the Covid-19 pandemic. Smartphones are used mainly by people aged 18-34 years (Ozdamli \& Cavus, 2011). Therefore, high school students are included in the most smartphone users. A large number of ownership and high use of smartphones can make smartphones as learning media. Currently, technology has not been used optimally. Most students do not use smartphones well, only for games and social media (Ardiansyah \& Nana, 2020). So special attention is needed to make technology, especially in education, more valuable.

Buffer solutions material is one of the materials in chemistry full of theoretical concepts and calculations. This buffer solutions material is also difficult for students to understand because there are many theories and calculation formulas. The results of the analysis of student needs also show that $67.7 \%$ of students' buffer solutions is a material that is difficult to understand. This is because the material has concepts that are difficult to understand; $62.9 \%$ of students feel that it is too much to memorize, and $35.15 \%$ feel that the learning is not interesting, the remaining $11 \%$ is due to the teacher's delivery and the absence of learning media. Bunce (2009) states that to be successful in chemistry requires good understanding, not memorizing. To make it easier to study chemical material that contains abstract and microscopic concepts, a technology-based learning media can be utilized. Teachers can use ICT-based learning media, which is mobile learning media. Mobile learning has become a popular learning media, especially in universities worldwide, because of its multi- function and effectiveness. Mobile learning reflects a learning strategy by teachers for distance teaching because it helps them learn from anywhere and anytime (Biswas et al., 2020). It is also an alternative learning method during the Covid-19 pandemic (Herliandry et al., 2020; Naciri et al., 2020).

Mobile learning is a learning media that utilizes telephone technology (Ardiansyah \& Nana, 2020). Mobile learning occurs when students have access to find information anytime and anywhere via mobile technology to carry out activities in the context of their learning (Martin \& Ertzberger, 2013). Mobile learning uses smartphones, tablets, netbooks, or notebooks as a learning tool and is part of learning through electronics (e-learning). Therefore, mobile learning is more flexible than e-learning because students can learn anywhere and anytime (Ally \& PrietoBlázquez, 2014; Kukulska-hulme, 2012).

Mobile learning is an important factor in the learning process that is not applicable for $21^{\text {st }}$ century students using mobile devices because mobile learning can improve student learning, contribute positively to student engagement, and positively affect the academic field (Lestari et al., 2019). Mobile learning equipped with multimedia elements has a role to generate new interest in learning and generate motivation for student learning activities.

Increased motivation due to learning with mobile learning applications composes the concept that students can learn anytime and anywhere. Students can use mobile learning applications in the environment or conditions they want, so it is expected to increase the motivation of student learning activities. This is in line with the results of previous research (Chung et al., 2013; Laila et al., 2016), which revealed that mobile learning could facilitate students in learning anytime and anywhere and increase students' motivation and memory can be used repeatedly.

Because the benefits of mobile learning are so felt, various kinds of mobile learning 
Development of Mobile Learning integrated with Learning Management System (LMS) on Buffer Solutions Topic

development models have emerged to provide a quality learning experience to students. Mobile learning can be integrated with the help of various software and hardware technologies into multimedia applications that can facilitate communicate educational formats in various formats such as games, short messages, quizzes, and multimedia content. One of them is to integrate it with LMS. Most universities provide a platform for learning in LMS for all subjects. LMS can support interaction between students and lecturers (Hanafi et al., 2020).

LMS is a resource management system used in web-based learning media or e-learning (Sicat, 2015). LMS (e.g., Moodle, Blackboard) is considered a Web 2.0 application that combines multimedia resources for various educational activities, serves as an online platform for group discussions, uploading course materials, and grading assignments (Hu et al., 2019). Some of the provision of mobile learning applications is provided through a LMS to improve students' learning experience (Hung et al., 2015). LMS can make the provision of teaching and learning materials and activities more efficient (Lonn \& Teasley, 2009).

Mobile learning applications integrated with the LMS can increase learning motivation and are expected to assist educators in choosing educational applications that suit the characteristics of students. This is in line with research conducted by previous studies (Adinugroho et al., 2015; Al-Kindi \& Al-Suqri, 2017; Antonenko et al., 2013; Hu et al., 2019; Setiawati et al., 2012).

Based on this background, the researchers are interested in developing the media mobile learning integrated with LMS to improve student learning motivation on buffer solutions topic.

The learning process uses a scientific approach with a discovery learning model. According to the Ministry of Education and Culture (in teacher training materials for implementing the 2013 curriculum), discovery learning is a

\section{Research Method}

This research uses the Research and Development ( $R \& R \& D$ ) method of the Borg and Gall model, which has been modified into five stages: preliminary analysis, product development, product validation, product testing, and implementation with quantitative methods. The study was conducted at SMA ALHASRA from November 2020 to June 2021. The sample in this study was 51 students of $11^{\text {th }}$ grade natural science 1 and 2 of SMA AlHasra. The sampling technique used in this research is purposive sampling.

At the validation stage, the researcher conducted a feasibility test/validation of the mobile learning media product integrated with the LMS developed for the validator, with expert validators: media experts, material experts, and language experts. After that, do the testing phase. The trial phase was carried out on a small and large scale.

The media that has been developed is then implemented and tested using quantitative methods with a quasi-experimental research design. The form of the research design chosen is a post-test only control group design.

This research was divided into two classes: the experimental and control classes. The experimental class is a class that uses integrated mobile learning and LMS. While the control class is a class that uses PowerPoint. The post-test only control group design scheme is shown in Table 1 as follows:

Table 1. Research Design

\begin{tabular}{lll}
\hline Group & Treatement & Measurement \\
\hline Control & $\mathrm{X}$ & $\mathrm{O}_{1}$ \\
Experiment & $\mathrm{Y}$ & $\mathrm{O}_{2}$ \\
\hline
\end{tabular}

Description:

$X=$ Using PowerPoint media

$\mathrm{Y}=$ Using Mobile Learning integrated LMS

$\mathrm{O}_{1}$ dan $\mathrm{O}_{2}=$ Giving motivational questionnaires for the experimental class and the control class after treatment 
The learrning process uses a scientific approach with a discovery learning model. According to Ministry of Education and Culture (in teacher training materials for implementing the 2013 curriculum), discovery learning is a learning theory that is defined as a learning process that occurs when students are not presented with the subject matter in a final form but are expected to organize themselves.

The instrument used in this study was a student learning motivation questionnaire compiled based on the characteristics of learning motivation by Sardiman (2012), which was developed as an indicator of learning motivation. Then, the data is tested for validation and reliability. The data were analyzed first by prerequisite tests, which are normality and homogeneity tests. Hypothesis test using t-test (independent sample t-test.). Hypothesis testing is used to prove that the integrated mobile learning media LMS in buffer solutions subjects will positively affect students' learning motivation.

\section{Result and Discussion}

\subsection{LMS Main Page Display}

The mobile learning application created is called buffer solutions and can be installed by students using the link http://fromedia.id/Solutions-buffer/. After downloading and installing, the application can then be used on the smartphones of teachers and students. This LMS view requires an administrator to create and manage LMS accounts. The display link to download the mobile learning application can be seen in Figure 1.

Main menu display/main home: after downloading the mobile learning application and loading, mobile learning will go to the main menu. The main menu consists of competency features, buffer solutions material, learning videos, chemistry classes (kimi), quizzes, and discussion rooms. Furthermore, a sound button functions to turn on the back sound, a home button to return to the main display, and an exit button (blue sign) are used to exit the mobile learning application, as in Figure 2.

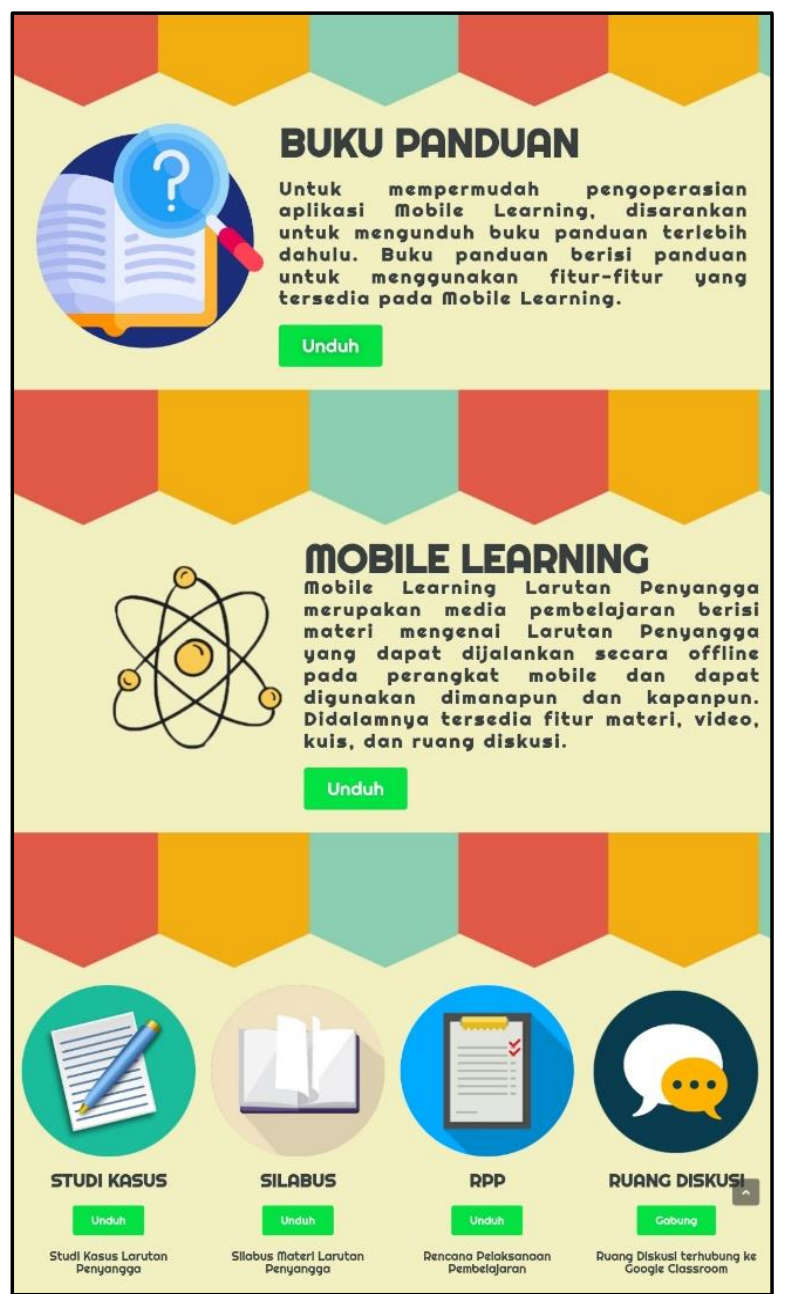

Figure 1. LMS Main Page Display

Field trials are mobile learning media trials conducted on several teachers and students based on the results of product development revisions that have been carried out in expert trials. The feasibility test for material and language experts is $82.25 \%$ with a reliability of 0.975 and a media feasibility test of $75.05 \%$ with a reliability of 0.960 . The trial conducted by the teacher was $83.15 \%$. While the smallscale student trial was $83.02 \%$ and the largescale was $79.5 \%$, the feasibility of the data and the trial had very good criteria. 


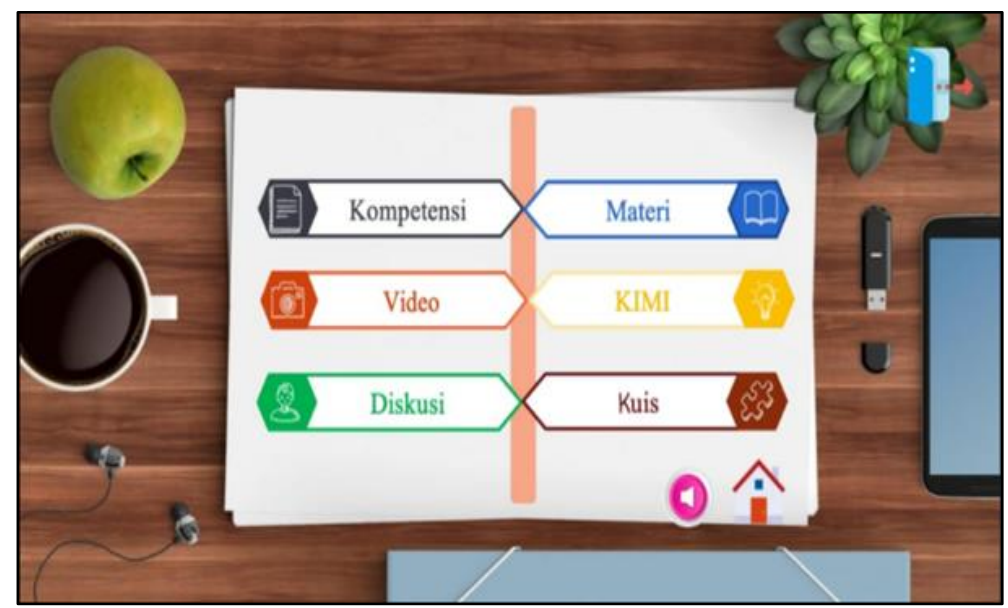

Figure 2. Main Menu Display

After developing mobile learning media, the next step is to test students' learning motivation. In this study, a learning motivation questionnaire was compiled based on its characteristics which were developed into ten indicators: persistence to face tasks, perseverance to face difficulties, happiness to learn independently, trying to explore the subject matter, trying to excel, an interest in new problems, full of enthusiasm, can defend the opinion that is believed, pleasure in finding and solving problems, and pleasure in doing tasks.

Table 2. Results of Student Learning Motivation on Mobile Learning

\begin{tabular}{clcc}
\hline No & \multicolumn{1}{c}{ Aspect } & Feasibility Percentage & Criteria \\
\hline 1 & Perseverance to face the task & $73.8 \%$ & Good \\
2 & Perseverance to face adversity & $73.2 \%$ & Good \\
3 & Happy to learn independently & $66.3 \%$ & Good \\
4 & Trying to explore the subject matter & $73.0 \%$ & Good \\
5 & Striving to excel & $70.4 \%$ & Good \\
6 & Interest in new problems & $68.2 \%$ & Good \\
7 & Full of spirit & $71.7 \%$ & Good \\
8 & Can defend the opinion that is believed & $63.1 \%$ & Good \\
9 & Fun in finding and solving problems & $67.0 \%$ & Good \\
10 & Having fun doing the job & $60.8 \%$ & Fair \\
\hline \multicolumn{2}{r}{ Average } & $68.4 \%$ & Good \\
\hline
\end{tabular}

This instrument is then tested for validity and reliability. This instrument was validated by two expert lecturers in the chemistry education department of Universitas Negeri Jakarta and was trialed by 30 students in different classes, then the reliability and validity were calculated using SPSS version 23.0, with the R-value 0.898. After the motivation questionnaire instrument was tested for validity and reliability, the next step was to collect data. The results of students' learning motivation towards LMS integrated mobile learning can be seen in Table 2.
From the results of data analysis in Table 2, it is known that the average value of student learning motivation is $68.4 \%$. Thus, it can be seen that students' learning motivation is in a good category.

Based on the results of the motivation questionnaire, a prerequisite analysis test was carried out to determine the level of normality and homogeneity of the research data. The Kolmogorov-Smirnov normality test uses a formula carried out by the Asymp rule. Sig or $p$-value at the $5 \%$ alpha significance level. If $p$ 
Development of Mobile Learning integrated with Learning Management System (LMS) on Buffer Solutions Topic

$>0.05$, then the data is normally distributed. This normality calculation uses SPSS computer assistance version 23.0. The normality test results calculated using SPSS version 23.0 can be seen in Table 3.

Table 3. Normality Test Result

\begin{tabular}{ccccccc}
\hline \multirow{2}{*}{ Class } & \multicolumn{3}{c}{ Kolmogorov-Smirnov } & \multicolumn{3}{c}{ Shapiro-Wilk } \\
\cline { 2 - 7 } & Statistic & Df & Sig. & Statistic & Df & Sig. \\
\hline $11^{\text {th }}$ grade natural science 2 & 0.128 & 25 & $0.200^{\star}$ & 0.951 & 25 & 0.257 \\
$11^{\text {th }}$ grade natural science 1 & 0.104 & 25 & $0.200^{\star}$ & 0.966 & 25 & 0.541 \\
\hline
\end{tabular}

* This is a lower bound of the true significance

a. Lilliefors Significance Correction

From the normality test results in Table 3 , it is known that the variable being tested, which is students' learning motivation, has an Asymp value. Sig. is greater than 0.05 . It was concluded that the research variables were normally distributed.

The homogeneity test was conducted using the Levene Statistics test through the SPSS 23.0 program. The homogeneity test results calculated using SPSS version 23.0 can be seen in Table 4. From Table 4, it is shown that the value of sig. The variable of students' learning motivation is greater than 0.05 . It is concluded that students' learning motivation has the same variance (homogeneous).
Table 4. Homogeneity Test Result

\begin{tabular}{lccc}
\hline Levene Statistic & df1 & df2 & Sig. \\
\hline 0.015 & 1 & 48 & 0.903 \\
\hline
\end{tabular}

After conducting the prerequisite test using the normality test and the homogeneity test, it was concluded that the data were normally distributed. Then it can be done by testing the hypothesis using parametric statistics with an independent sample t-test. An independent sample t-test was done using SPSS 23 software. The results of the t-test can be seen in Table 5.

Table 5. Result of Independent Sample t-Test

\begin{tabular}{lcccccc}
\hline \multicolumn{1}{c}{ Groups } & $\mathbf{n}$ & $\mathbf{M}$ & SD & $\boldsymbol{T}$ & $\boldsymbol{d f}$ & $\boldsymbol{p}$ \\
\hline Experimental & 25 & 106.56 & 7.517 & & 48 & 0.00 \\
Control & 26 & 85.19 & 7.568 & & & 4798 \\
\end{tabular}

Based on Table 5, the data from the independent sample t-test results obtained the value of Sig. (2-tailed) 0.000 . This indicates Sig. (2-tailed) $<\mathrm{H}_{0}$ was rejected and obtained $t_{\text {count }}$ of 10.045 and $t_{\text {table }}$ of 1.685. This indicates that the number of $t_{\text {count }}$ is greater than $t_{\text {table. It }}$ can be concluded that there is a significant positive effect from the use of integrated mobile learning media LMS to increase students' learning motivation in learning chemistry of buffer solutions topic.

\subsection{The Effect of Student Learning Motivation on the Buffer Solutions Material between Students LMS and Students Using PowerPoint}

Testing the hypothesis between students who use mobile learning media integrated LMS obtained a learning motivation score with an average of 106.56 while the group of students who use PowerPoint obtained a learning motivation score with an average of 85.19.

The use of mobile learning provides teachers with the benefits of teaching without being limited by time and place, enabling learning to 
continue after class ends or outside the classroom where learning occurs naturally (Zydney \& Warner, 2016). This kind of learning media can help improve student' academic performance in learning outcomes in the cognitive domain and students' learning motivation (Abidin et al., 2014; Yektyastuti, 2016). Upbeat on the cognitive, metacognitive, affective, and socio-cultural dimensions. Smartphones and tablets have the power to transform the learning experience. Mobile learning also has advantages because it is integrated with the LMS.

LMS is a web 2.0 application that combines rich multimedia resources for various educational activities, serves as an online platform for group discussions, uploading course materials, and grading assignments (Hu et al., 2019). This is consistent with previous research that mobile learning integrated LMS can increase student motivation to learn and promote collaborative learning (Black et al., 2008; Cavus et al., 2007; Ouadoud et al., 2017). Active implementation and use of LMS have proven to be very effective in increasing student engagement in higher education (Barua et al., 2018; Horvat et al., 2015). So that mobile learning that is integrated with the LMS makes it convenient for students to access chemistry materials and information in an easy and timely manner.

In contrast to the case with students who are taught using traditional media, this study was formed in PowerPoint media. PowerPoint media does not support the formation of meaningful learning because it does not stimulate students' audio and visuals (Penciner, 2013). Teachers also have to prepare laptops/computers and projectors to display them in the classroom, and not all teachers can operate PowerPoint efficiently. Not only that, but making PowerPoint also requires special skills to display excellent and interactive PowerPoint. PowerPoint is only used for teachers to deliver material during the learning process. Generally, PowerPoint media is only in the form of impressions combined with the lecture method that the teacher gives when explaining learning material in class so that students tend to passively only receive information. This causes students to become bored and sleepy because students are not actively involved (Boumová, 2008). So that learning is still centered on the teacher and students cannot use learning media optimally.

Based on Table 5, the data from the independent sample t-test results obtained the value of Sig. (2-tailed) 0.000 . This indicates Sig. (2-tailed) $<\mathrm{H}_{0}$ was rejected and obtained $t_{\text {count }}$ of 10,045 and $t_{\text {table }}$ of 1,685 . This indicates that the number of $t_{\text {count }}$ is greater than $t_{\text {table. }}$. So it can be concluded that $\mathrm{H}_{0}$ is rejected and $\mathrm{H}_{1}$ is accepted or the hypothesis is accepted, which means that there is a significant positive effect from the use of mobile learning media integrated LMS to increase students' learning motivation in learning chemistry buffer solutions topic.

This is consistent with previous research that mobile learning integrated LMS can increase student motivation to learn and promote collaborative learning (Black et al., 2008; Cavus et al., 2007; Ouadoud et al., 2017). In addition, the application of finding information through mobile learning is an effective way because it can attract, encourage and motivate to increase theoretical knowledge and skills (Apostolov \& Milenkova, 2018).

Mobile learning is unique because students can access materials, directions, and applications related to learning anytime and anywhere. This will increase attention to learning materials, make learning persuasive, and encourage learner motivation for lifelong learning. Learning motivation must be increased so that teachers must design learning according to the criteria with mobile learning. With the development of mobile learning, an integrated LMS provides opportunities for the government, schools, teachers, and students to increase their learning motivation. The resulting learning media can be used by participants so that students' learning motivation can increase, especially in the buffer solutions topic. 
Development of Mobile Learning integrated with Learning Management System (LMS) on Buffer Solutions Topic

\section{Conclusion}

The study result concluded that using the integrated mobile learning application LMS positively affected students' learning motivation.

During the Covid-19 pandemic, classroom activities were eliminated. The government and schools should think about how to solve this problem. One alternative that teachers widely use is mobile learning. Mobile learning is just a learning tool that will not change or improve academic achievement if it is only seen as a means of storing material and providing assignments without providing learning scenarios that must be in it.

Learning motivation must be increased so that teachers must design learning according to the criteria with mobile learning. With the development of mobile learning, an integrated LMS provides opportunities for the government, schools, teachers, and students to increase their learning motivation.

Based on the findings of this study, it is suggested that integrated mobile learning can continue to be implemented not only during the Covid 19 pandemic, and learning using integrated mobile learning and LMS can be developed by teachers on an ongoing basis for different subjects and materials.

\section{References}

Abidah, A., Hidaayatullaah, H. N., Simamora, R. M., Fehabutar. D., \& Mutakinati, L. (2020). The Impact of Covid-19 to indonesian education and its relation to the philosophy of "merdeka belajar". Studies in Philosophy of Science and Education (SiPOSE). 1(1). 38-49. https://doi.org/10.46627/sipose.v1i1.9

Abidin, A., Marzal, J., \& Rohati, R. (2014). Pengembangan media pembelajaran matematika interaktif berbasis android untuk menumbuhkan motivasi belajar anak disleksia pada materi eksponensial di Kota Jambi. Edumatica:
Jurnal Pendidikan Matematika, 4(02). https://doi.org/10.22437/edumatica.v 4i02.2072

Adinugroho, T. Y., Reina, \& Gautama, J.B. (2015). Review of multi-platform mobile application development using WebView: Learning management system on mobile platform. International Conference on Computer Science and Computational Intelligence (ICCSCI 2015). 291-297. https://doi.org/10.1016/j.procs.2015.0 7.568

Al-Kindi, S. S., \& Al-Suqri, M. N. (2017). Mobilizing learning: Using moodle and online tools via smartphones. International Journal of Knowledge Content Development \& Technology, $7(3)$, https://doi.org/10.5865/IJKCT.2017.7.3 .067

Ally, M., \& Prieto-Blázquez, J. (2014). What is the future of mobile learning in education?. International Journal of Educational Technology in Higher Education, 11(1), 142-151. https://doi.org/10.7238/rusc.v11i1.203 3

Antonenko, P. D., Derakhshan, N., \& Mendez, J. P. (2013). Pedagogy 2 go: Student and faculty perspectives on the features of mobile learning management systems. International Journal of Mobile Learning and Organisation, 7(3-4), 197-209. Retrieved from https://www.inderscienceonline.com/d oi/pdf/10.1504/IJMLO.2013.057161

Apostolov, G., \& Milenkova, V. (2018). Mobile learning and digital literacy in the context of university young adults. $14^{\text {th }}$ International Conference Mobile Learning 2018. Retrieved from 105112.

https://files.eric.ed.gov/fulltext/ED590 355.pdf 
Development of Mobile Learning integrated with Learning Management System (LMS) on Buffer Solutions Topic

Ardiansyah, A. A., \& Nana. (2020). Peran mobile learning sebagai inovasi dalam meningkatkan hasil belajar siswa pada pembelajaran di sekolah. Indonesian Journal of Educational Research and Review. 3(1), 47-56. http://dx.doi.org/10.23887/ijerr.v3i1.2 4245

Asmara, A. P. (2015). Pengembangan media pembelajaran berbasis audio visual tentang pembuatan koloid. JURNAL ILMIAH DIDAKTIKA: Media Ilmiah Pendidikan dan Pengajaran, 15(2), 156178.

http://dx.doi.org/10.22373/jid.v15i2.57 8

Barua, P. D., Zhou, X., Gururajan, R., \& Chan, K. C. (2018). Determination of factors influencing student engagement using a learning management system in a tertiary setting. In 2018 IEEE/WIC/ACM international conference on Web Intelligence (WI) (pp. 604-609). Santiago, Chile: IEEE. https://doi.org/10.1109/WI.2018.0030

Biswas, B., Roy, S. K., \& Roy, F. (2020). Students perception of mobile learning during Covid-19 in Bangladesh: University student perspective. Aquademia, 4(2), ep20023. Retrieved from https://papers.ssrn.com/sol3/papers.cf m?abstract_id $=3667908$

Black, E. W., Dawson, K., \& Priem, J. (2008). Data for free: Using LMS activity logs to measure community in online courses. The Internet and Higher Education, 11(2), 65-70. https://doi.org/10.1016/j.iheduc.2008. 03.002

Boumová, V. (2008). Traditional vs. Modern Teaching Methods: Advantages and Disadvantages of Each. Ceko: Masaryk University Faculty of Arts. https://is.muni.cz/th/86952/ff_m_b1/m grdiplomkaboumova.pdf
Bunce, D. M. (2009). Teaching is more than lecturing and learning is more than memorizing: 2007 james flack norris award. Journal of Chemical Education, 86(6), 674-680. https://doi.org/10.1021/ed086p674

Cavus, N., Uzunboylu, H., \& Ibrahim, D. (2007). Assessing the success rate of students using a learning management system together with a collaborative tool in web-based teaching of programming languages. Journal of Educational Computing Research, 36(3), 301-321. https://doi.org/10.2190/T728-G6764N18-6871

Chung, C. H., Pasquini, L. A., \& Koh, C. E. (2013). Web-based learning management system considerations for higher education. Learning and Performance Quarterly, 1(4), 24-37. Retrieved from https://www.researchgate.net/publicat ion/235956447_Web-

based_Learning_Management_System _Considerations_for_Higher_Education

Hanafi, Y., Murtadho, N., Ikhsan, M. A., \& Diyana, T. N. (2020). Reinforcing public university student's worship education by developing and implementing mobilelearning management system in the ADDIE instructional design model. International Journal of Interactive Mobile Technologies (i/M). 14(2). Retrieved from https://www.researchgate.net/publicat ion/339151162_Reinforcing_Public_Un iversity_Student\%27s_Worship_Educat ion_by_Developing_and_Implementin g_Mobile-

Learning_Management_System_in_the _ADDIE_Instructional_Design_Model

Herliandry, L. D., Nurhasanah, Suban, M. E., Kuswanto, H. (2020). Pembelajaran pada masa pandemi Covid-19. Jurnal Teknologi Pendidikan. 22(1). 65-70. https://doi.org/10.21009/jtp.v22i1.152 86 
Development of Mobile Learning integrated with Learning Management System (LMS) on Buffer Solutions Topic

Horvat, A., Dobrota, M., Krsmanovic, M., \& Cudanov, M. (2015). Student perception of Moodle learning management system: A satisfaction and significance analysis. Interactive Learning Environments, 23(4), 515527.

https://doi.org/10.1080/10494820.201 3.788033

Hu, X., Ng, J., Tsang, K. K., \& Chu, S. K. (2019). Integrating Mobile Learning to Learning Management System in Community College. Community College Journal of Research and Practice, 44(10-12), 722-737. https://doi.org/10.1080/10668926.201 9.1640146

Hung, P., Lam, J., Wong, C., \& Chan, T. (2015). $A$ study on using learning management system with mobile app. International Symposium on Educational Technology (ISET), 168172). IEEE. https://doi.org/10.1109/ISET.2015.41

Kemendikbud. (2020). Ministry of Education and Culture No. 4 \& 15 2020. Jakarta: Kemendikbud

Kukulska-Hulme, A. (2012). Smart devices or people? a mobile learning quandary. International Journal of Learning and Media. 4(3-4), 73-77. https://doi.org/10.1162/IJLM_a_00105

Laila, K. N., Martin HB, F. P., \& Irsadi, A. (2016). Efektifitas media pembelajaran androplantae berbasis android pada materi dunia tumbuhan untuk siswa SMA. Unnes Journal of Biology Education. 5(2), 110-115. Retrieved from

https://journal.unnes.ac.id/sju/index.p hp/ujbe/article/view/14651

Lestari, I., Maksum A., \& Kustandi C. (2019). Mobile learning design models for state university of Jakarta, Indonesia. International Journal of Interactive Mobile Technologies (Ijim). 13(9). 152-
171.

https://doi.org/10.3991/ijim.v13i09.10 987

Lonn, S., \& Teasley, S. D. (2009). Saving time or innovating practice: Investigating perceptions and uses of learning management systems. Computers \& education, 53(3), 686-694. https://doi.org/10.1016/j.compedu.20 09.04.008

Martin, F., \& Ertzberger, J. (2013). Here and now mobile learning: An experimental study on the use of mobile technology. Computers and Education, 68, 76-85. https://doi.org/10.1016/j.compedu.20 13.04.021

Naciri, A., Baba, M. A., Achbani, A., \& Kharbach, A. (2020). Mobile Learning in Higher Education: Unavoidable Alternative during COVID-19. Aquademia, 4(1), ep20016.

https://doi.org/10.29333/aquademia/ 8227

Ouadoud, M., Nejjari, A., Chkouri, M. Y., \& ElKadiri, K. E. (2017). Learning management system and the underlying learning theories: In Proceedings of the Mediterranean Symposium on Smart City Applications (732-744). Springer, Cham. https://doi.org/10.1007/978-3-31974500-8_67

Ozdamli, F., \& Cavus, N. (2011). Basic elements and characteristics of mobile learning. Procedia-Social and Behavioral Sciences, 28, 937- 942. https://doi.org/10.1016/j.sbspro.2011. 11.173

Penciner, R. (2013). Does powerpoint enhance learning? Canadian Journal of Emergency Medicine, 15(2), 109 - 112. https://doi.org/10.2310/8000.2013.13 0756

Setiawati, N., Kartika, I., \& Purwanto, J. (2012). Pengembangan mobile learning ( $\mathrm{m}$ - 
Development of Mobile Learning integrated with Learning Management System (LMS) on Buffer Solutions Topic

learning) berbasis moodle sebagai daya dukung pembelajaran fisika di SMA. In Prociding: Seminar Nasional Fisika dan Pendidikan Fisika, 3(3), 178186. Retrieved from https://www.academia.edu/download/ 44978690/penelitian_relevan_1.pdf

Sicat, A. S. (2015). Enhancing college students' proficiency in business writing via schoology. International Journal of Education and Research. 3(1), 159-178. Retrieved from https://www.ijern.com/journal/2015/Ja nuary-2015/14.pdf

Silin, Y., \& Kwok, D. (2017). A study of students' attitudes towards using ict in a social constructivist environment. Australasian Journal of Educational
Technology, 33(5), 50-62. https://doi.org/10.14742/ajet.2890

Yektyastuti, R., \& Ikhsan, J. (2016). Pengembangan media pembelajaran berbasis android pada materi kelarutan untuk meningkatkan performa akademik peserta didik SMA. Jurnal Inovasi Pendidikan IPA. 2(1). 8899.

https://doi.org/10.21831/jipi.v2i1.1028 9

Zydney, J. M., \& Warner, Z. (2016). Mobile apps for science learning: Review of research. Computers \& Education 94, 1-17.

https://doi.org/10.1016/j.compedu.20 15.11.001 